\title{
MOGUĆNOST LAŽIRANJA REZULTATA NA TESTU PIE-JRS U SITUACIJI PROFESIONALNE SELEKCIJE
}

\author{
Predrag Okanović', Dragana Okanović \\ Odsek za psihologiju, Filozofski fakultet Novi Sad
}

Istraživanje je sprovedeno sa ciljem da se odgovori na dva pitanja: da li je moguće namerno lažiranje skorova na testu Profil indeks emocija u smislu boljeg predstavljanja, $i$ da li kandidati za posao zaista koriste tu mogućnost u situaciji profesionalne selekcije? Ukupan uzorak $(N=539)$ je činilo dve grupe ispitanika: (1) ispitanici koji su popunjavali test PIE-JRS na dva načina (prvo iskreno, a potom sa instrukcijom da se predstave na što bolji način) $i$ (2) realni kandidati za posao u procesu profesionalne selekcije. Sprovedene su dve odvojene analize kako bi se dao odgovor na dva istraživačka pitanja. Na osnovu prve sprovedene analize zabeležena je delimična podložnost lažiranju ovog testa - tri skale su demonstrirale otpornost na lažiranje, dok pet skala nije. Prilikom instruisanog lažiranja, ispitanici se najviše trude da se predstave kao poslušni i nekonfliktni kandidati (podizanjem skora na skali Inkorporacije i snižavanjem Agresije i Odbacivanja). Ovakav obrazac u odgovaranju je naročito uočljiv kod žena i pripadnika humanističkih struka. Na osnovu druge etape možemo zaključiti da kandidati na procesu selekcije zaista koriste mogućnost lažiranja odgovora - kada se porede ispitanici iz fiktivne i realne profesionalne selekcije, na pet skala testa PIE-JRS nema razlika, a na preostale tri realni kandidati postižu poželjnije rezultate.

Ključne reči: lažiranje rezultata, Profil indeks emocija, test prinudnog izbora, profesionalna selekcija

\footnotetext{
${ }^{1}$ Adresa autora: okanovici@neobee.net
} 


\section{Uvod}

Problem lažiranja rezultata (eng. „fakeability“) predstavlja jednu od osnovnih kontroverzi kada je u pitanju upotreba testova ličnosti u organizacionoj psihologiji. Rezultati na testovima često imaju značajno mesto prilikom odlučivanja o zaposlenju i unapređenju, tako da jasna veza između skora na testu i očekivane nagrade može dovesti do motivacije da se odgovori ulepšavaju. Javnost, kako stručna tako i poslovna, s pravom može postaviti pitanje: da li se testovi ličnosti mogu prevariti? Debata o ovom pitanju u akademskim krugovima traje već decenijama, jednako dugo koliko i zabrinutost praktičara koji se bave profesionalnom selekcijom. U jednoj od studija koja je obuhvatala anketiranje stručnjaka za profesionalnu selekciju, čak $69 \%$ njih je izjavilo da bi volelo da koristi testove koji sadrže neki od metoda za minimiziranje efekta lažiranja odgovora (Goffin \& Christiansen, 2003).

Za početak, osnovno pitanje u vezi sa ovom temom je da li se testovi ličnosti uopšte mogu namerno lažirati? Brojna istraživanja su ponudila dokaze za potvrdan odgovor (Heggestad, Morrison, Reeve \& McCloy, 2006; Judge, Klinger, Simon \& Yang, 2008; Sackett, 1994). Ova istraživanja su najčešće podrazumevala veštačku situaciju u kojoj su ispitanici bili instruisani da se predstave $u$ što boljem svetlu, što je uglavnom rezultiralo boljim skorovima na testovima. Dalje, pitanje je da li pravi kandidati za posao zaista koriste tu mogućnost? Odgovor je u većini slučajeva ponovo bio potvrdan - kandidati za posao redovno dostižu više skorove na poželjnim dimenzijama ličnosti nego nemotivisani ispitanici (Rosse, Stecher, Miller \& Levin, 1998; Ones, Viswesvaran \& Schmidt, 1993). Interesantno je da se kod kandidata za posao menja i faktorska struktura ličnosti, pri čemu se dobija faktor „idealnog radnika“ (Schmit \& Ryan, 1993).

Dosadašnja istraživanja su identifikovala tri obrasca koje kandidati koriste prilikom lažiranja testova (Sackett et al., 1989, prema Jackson et al., 2000): pozitivno lažiranje (generalno predstavljanje u boljem svetlu), negativno lažiranje (suprotno od prethodnog) i usklađivanje sa konkretnom radnom pozicijom. Prvi obrazac je najčešće korišćen u prethodnim studijama, a biće primenjen i u ovom istraživanju.

Kada je u pitanju metodologija istraživanja ove pojave, postoje dve dominantne istraživačke paradigme (Ellingson, Sackett \& Connelly, 2007). Prva podrazumeva korišćenje skala za identifikovanje socijalno poželjnih odgovora (eng. „lie-scales“), pri čemu visok skor na tim skalama vodi eliminisanju kandidata iz procesa selekcije ili primeni korekcije rezultata (umanjenje skora za određeni iznos). Ispravnost upotrebe ovih skala se dovodi u pitanje s obzirom da 
može eliminisati neke kandidate koji zapravo ne lažiraju odgovore namerno. Meta-analizom velikog broja studija je utvrđeno da skala socijalne poželjnosti poseduje visoku korelaciju sa skalama savesnosti i emocionalne stabilnosti, tako da bi njenim odstranjivanjem bio eliminisan i deo valjane varijanse (Ones, Viswesvaran \& Reiss, 1996).

Druga paradigma se zasniva na poređenju odgovora koje daju kandidati $u$ procesu profesionalne selekcije (ili ispitanici koji su instruisani da pozitivno lažiraju) i ispitanici koji nemaju takvu motivaciju. Ova paradigma dominira u odnosu na prvu, i biće primenjena i u ovom istraživanju.

Kako minimizirati efekte lažiranja? Najefikasniji način predstavlja uvođenje neke od alternativa upitnicima samoprocene, u vidu procene od strane kolega, supervizora ili HR menadžera/psihologa. Kako su upitnici samoprocene usled svoje ekonomičnosti nezamenjivi u praksi, potrebno je pronaći način da se poveća njihova vrednost putem snižavanja efekta lažiranja. Strategije koje se koriste u tu svrhu možemo podeliti u reaktivne i proaktivne (Judge et al., 2008). Skale socijalno poželjnih odgovora su svakako najpoznatiji reaktivni metod, ali iz gore navedenih razloga jasno je da njihova primena ima ograničenja. Proaktivni metodi se uglavnom oslanjaju na instrukciju ispitanicima da iskreno odgovaraju. Jedan od proaktivnih metoda koji se pokazao prilično efikasnim je konstruisanje upitnika prinudnog izbora.

\section{Tehnike prinudnog izbora}

Upitnici koncipirani na bazi prinudnog izbora predstavljaju razliku u odnosu na upitnike samoprocene sa jednim stimulusom (Likertovog tipa). Ispitanici u testovima prinudnog izbora moraju da izaberu jednu od dve ili više ponuđenih opcija, koje bi trebalo da su podjednako privlačne, ali da se razlikuju u prediktivnoj validnosti (Christiansen, Burns \& Montgomery, 2005).

Pokazalo se da u situacijama profesionalne selekcije ova tehnika bolje kontroliše grešku nastalu lažiranjem u odnosu na standardne upitnike Likertovog tipa. U studiji koju su sproveli Jackson i saradnici (2000) izvršeno je poređenje ova dva tipa upitnika. Ispitanici su imali instrukciju da popune upitnike (jedan Likertovog tipa i drugi prinudnog izbora) na dva načina: prvo iskreno, a potom i da pozitivno lažiraju odgovore. Pokazalo se da u situaciji lažiranja na upitnicima Likertovog tipa ispitanici postižu skorove koji su za celu standardnu devijaciju viši od standardnih, dok su skorovi na upitniku prinudnog izbora viši za tek trećinu standardne devijacije. Dodatno, prediktivna validnost kod upitnika prinudnog izbora je ostala praktično nepromenjena, dok se $\mathrm{u}$ drugom slučaju drastično smanjila. Ipak, postoji sumnja da u upitnicima pri- 
nudnog izbora konstruktna validnost može biti ugrožena prilikom lažiranja, te da oni s toga nisu pogodni za primenu u profesionalnoj selekciji (Heggestad et al., 2006).

Na osnovu dosadašnjih saznanja možemo zaključiti da tehnike prinudnog izbora pružaju određene mogućnosti za minimiziranje efekata lažiranja (za razliku od standardnih upitnika samoprocene). Da li će taj efekat biti manji ili veći zavisi od konkretnog instrumenta i odabira parova ajtema koji će uspeti da ostani imuni na lažiranje.

\section{Profil indeks emocija}

Najpoznatiji test ličnosti koji se primenjuje u praksi profesionalne selekcije $u$ Srbiji je Plučikov Profil indeks emocija (PIE). Svoju popularnost duguje jednostavnosti za administriranje (jednostavna instrukcija i kratko vreme izrade), kao i nedostatku konkurencije na ovim prostorima, što ga čini najzastupljenijim instrumentom u selekciji kadrova. Zasnovan je na Plučikovoj teoriji osam osnovnih emocija, koja ima tendenciju da obuhvati celu ličnost, pri čemu se emocije kombinuju i strukturišu crte ličnosti (Kostić, 2003).

PIE je klasičan test prinudnog izbora - sastoji se od 62 para osobina, pri čemu je zadatak ispitanika da u svakom paru zaokruži onu koja ga bolje opisuje. Interesantno je da tako ispitanici direktno procenjuju prisustvo 12 odabranih crta ličnosti, na osnovu kojih se dobija profil sačinjen od osam osnovnih emocija i BIAS-skale. Ovakav način odgovaranja je teži za kontrolu, i razlikuje se od standardnog, kada se o crtama ličnosti zaključuje posredno, odgovaranjem na određeni niz tvrdnji (Kurbalija, 2006).

Tabela 1. Subskale testa PIE-JRS zajedno sa atributima koji ih opisuju

\begin{tabular}{ll}
\hline testovni konstrukt & atributi u testu \\
\hline INKORPORACIJA & srdačna, društvena, poslušna \\
ZAŠTITA & oprezna, poslušna, nesigurna, stidljiva \\
ORIJENTACIJA & nagla, sklona pustolovinama \\
LIŠENOST & potištena, grize se u sebi \\
ODBACIVANJE & ozlojeđena, sklona prepirci, nesigurna \\
AGRESIJA & sklona prepirci, ozlojeđena \\
ISTRAŽIVANJE & oprezna, stidljiva, poslušna \\
REPRODUKCIJA & srdačna, društvena \\
\hline
\end{tabular}


Jugoslovenska revizija i standardizacija ovog testa, PIE-JRS, ima povoljne metrijske karakteristike (Kostić, 2003). Što je još značajnije za naše istraživanje, norme koje su dobijene na jugoslovenskom uzorku, prema rečima autora standardizacije, u velikoj meri čine ovaj test otpornim na varanje prilikom profesionalne selekcije. Naime, poređenjem uzorka kandidata za upis u vojnu školu i normativnog uzorka nisu dobijene značajne razlike u prosečnim skorovima na sedam od devet skala (izuzetak su skale Reprodukcije i Istraživanja).

\section{Problem istraživanja}

Osnovni problem istraživanja se sastoji u pitanjima: da li je moguće namerno lažiranje skorova na testu PIE-JRS u smislu boljeg predstavljanja i da li kandidati za posao zaista koriste tu mogućnost u situaciji profesionalne selekcije? Prethodni nalaz o otpornosti na lažiranje testa PIE-JRS, zajedno sa delimičnim potvrdama da testovi prinudnog izbora mogu da minimiziraju efekat lažiranja $\mathrm{u}$ situaciji profesionalne selekcije, predstavljaju dovoljan razlog da se Profil indeks emocija stavi na test otpornosti na varanje. Njegova dominantna pozicija u praksi organizacione psihologije u Srbiji još više nameće neophodnost izučavanja ovog fenomena.

\section{Metod}

\section{Uzorak}

Istraživanje je sprovedeno na ukupnom uzorku od 539 ispitanika oba pola, 228 muškaraca (42.3\%) i 311 žena (57.7\%). Ukupan uzorak možemo podeliti u dve grupe. Prvu čine ispitanici koji su dva puta popunjavali PIE-JRS, te stoga imaju dva skora na testu: normativni (iskreno odgovaranje) i instruisani (sa instrukcijom da se predstave na što bolji način). Taj deo uzorka čine pretežno studenti (70\%), a podaci su od njih prikupljani tokom novembra i decembra 2008., putem grupnog testiranja na Filozofskom fakultetu i Fakultetu tehničkih nauka u Novom Sadu, kao i putem interneta (studentske mailing-liste i direktno slanje). Druga grupa ispitanika je sačinjena od kandidata za posao koji su se nalazili u realnoj situaciji profesionalne selekcije (selekcioni uzorak). Ovu grupu čine kandidati na 23 različite profesionalne selekcije koje je u trogodišnjem periodu, 2006-2008. godine, sprovela Agencija TIM (agencija za primenjenu psihologiju koja pruža usluge profesionalne selekcije za svoje klijente). Svi ispitanici se nalaze u starosnom rasponu 22-30 godina. 
Predrag Okanović, Dragana Okanović

Tabela 2. Uzorak ispitanika

\begin{tabular}{lccccccc}
\hline & & prosek & pol & & \multicolumn{3}{c}{ oblast obrazovanja } \\
uzorak & $\mathrm{N}$ & godina & $\mathrm{m}$ & ž & $\begin{array}{l}\text { humanis- } \\
\text { tička }\end{array}$ & $\begin{array}{l}\text { teh- } \\
\text { nička }\end{array}$ & ostalo \\
\hline $\begin{array}{l}\text { normativni/ } \\
\text { instruisani }\end{array}$ & 288 & 24.4 & $31.3 \%$ & $68.8 \%$ & $55 \%$ & $29 \%$ & $16 \%$ \\
selekcioni & 251 & 27.4 & $55.0 \%$ & $45.0 \%$ & $14 \%$ & $39 \%$ & $47 \%$ \\
\hline
\end{tabular}

\section{Instrumenti i procedura istraživanja}

U istraživanju je korišćen test Profil indeks emocija - jugoslovenska revizija $i$ standardizacija (PIE-JRS, Kostić, 2003). Ovom prilikom su korišćene dve verzije. Prva je standardna verzija, koju su ispitanici popunjavali u skladu sa propisanim uputstvom. Druga verzija umesto standardnog uputstva sadrži instrukciju: "Sada Vas molimo da popunite isti test, ali da pritom zamislite da se nalazite u situaciji profesionalne selekcije za posao koji jako želite da dobijete. Dakle, ovaj put nije potrebno da odgovarate iskreno, već da se predstavite u što boljem svetlu, da ostavite najbolji mogući utisak”. Ispitanici iz normativnog/instruisanog dela uzorka su prvo popunjavali standardnu verziju, a odmah potom i instruisanu verziju. Kandidati za posao su popunjavali samo standardnu verziju testa.

U analizu je uvršteno osam skala testa. U cilju izbegavanja savršene multikolinearnosti, skala BIAS je isključena iz analize.

Ovim testovima je priključen i set demografskih varijabli (pol, starost, stručna sprema i oblast obrazovanja). Pored uloge u opisu uzorka, varijable pol i oblast obrazovanja su korišćene $u$ analizi. Oblast obrazovanja su ispitanici samostalno navodili, i nakon kategorisanja odgovora dobijene su dve kategorije: humanistička $(\mathrm{N}=159)$ i tehnička $(\mathrm{N}=83)$. S obzirom da su preostale kategorije oblasti obrazovanja bile vrlo male, 46 ispitanika je isključeno iz analiza u kojima je korišćena ova varijabla.

\section{Rezultati}

Analiza rezultata se sastoji iz dve etape, koje odgovaraju na pitanja navedena u okviru problema istraživanja: (1) da li je moguće namerno lažiranje skorova na testu PIE-JRS u smislu boljeg predstavljanja, i (2) da li kandidati za posao koriste mogućnost lažiranja u situaciji profesionalne selekcije? Ove etape podrazumevaju dve odvojene analize koje će biti predstavljene u nastavku teksta. 


\section{Prva etapa}

Prva etapa odgovara na pitanje da li je moguće namerno lažiranje skorova na testu PIE-JRS u smislu boljeg predstavljanja? Da bi se ispunio ovaj cilj, izvršeno je poređenje rezultata koje su postigli ispitanici na dva merenja: normativnom („popunite test iskreno“) i instruisanom („predstavite se u što boljem svetlu“). Preglednom deskriptivne statistike utvrđeno je da su skorovi na osam skala u proseku promenjeni za trećinu standardne devijacije. Sve skale su prilikom instruisanog odgovaranja pomerene u logičnom pravcu - poželjne dimenzije su povećane, nepoželjne snižene. Najveće promene su pretrpele skale Inkorporacije, Odbacivanja i Agresije.

Tabela 3. Prosečni skorovi na skalama PIE-JRS za normativno i instruisano merenje

\begin{tabular}{lll}
\hline & normativno merenje & instruisano merenje \\
\hline SKALA & AS (SD) & AS (SD) \\
\hline INKORPORACIJA & $62.38(29.57)$ & $82.68(24.15)$ \\
ZAŠTITA & $61.30(27.78)$ & $74.10(22.37)$ \\
ORIJENTACIJA & $44.40(27.79)$ & $38.03(23.83)$ \\
LIŠENOST & $51.08(28.82)$ & $47.88(28.02)$ \\
ODBACIVANJE & $41.48(27.82)$ & $25.90(23.86)$ \\
AGRESIJA & $38.83(28.03)$ & $23.75(23.17)$ \\
ISTRAŽIVANJE & $59.52(27.90)$ & $62.71(20.64)$ \\
REPRODUKCIJA & $61.01(31.69)$ & $73.09(27.73)$ \\
\hline
\end{tabular}

Kako bi se statistički poredile dobijene razlike, korišćena je dvosmerna multivarijatna analiza varijanse za ponovljena merenja. U analizu su kao zavisne varijable uvrštene sve skale PIE-JRS na dva merenja (osam varijabli puta dva merenja), dok su kao kategorijalni prediktori korišćeni pol i oblast obrazovanja. Rezultati se nalaze u Tabeli 4.

Tabela 4. MANOVA za ponovljena merenja - efekat merenja i interakcije merenja sa kategorijalnim prediktorima

\begin{tabular}{llllll}
\hline & SS & df & MS & F & $\mathrm{p}$ \\
\hline merenje & 991 & 1 & 991 & 8.03 & .01 \\
merenje $\times$ varijable & 96464 & 7 & 13781 & 24.77 & .00 \\
merenje $\times$ varijable $\times$ pol & 2933 & 7 & 419 & .75 & .68 \\
$\begin{array}{l}\text { merenje } \times \text { varijable } \times \text { oblast obrazovanja } \\
\text { merenje } \times \text { varijable } \times \text { pol } \times\end{array}$ & 21960 & 7 & 3137 & 5.64 & .00 \\
ob.obrazovanja & 13568 & 7 & 1938 & 3.48 & .00 \\
\hline
\end{tabular}


Rezultati MANOVA-e pokazuju značajnost glavnog efekta merenja, ali i interakcije merenja sa varijablama (skalama PIE-JRS), polom i oblasti obrazovanja. Kako bi se stekao detaljniji uvid u dobijene rezultate, sproveden je niz Posthoc analiza putem Scheffe testa.

Odgovor na pitanje da li je namerno lažiranje ovog testa moguće dobija se poređenjem skorova na normativnom i instruisanom merenju. Pet skala se pokazalo neotpornim na lažiranje (skorovi između dva merenja se statistički značajno razlikuju), dok su se tri skale pokazale otpornim (Tabela 5). Skala Inkorporacije je najpodložnija lažiranju, što i ne čudi s obzirom na to da se odnosi na poslušnost, osobinu koja se tokom selekcionog postupka visoko kotira kod poslodavaca. Ispitanici su skor na ovoj skali nakon instrukcije povisili za više od 20 jedinica, što govori da je po njihovom mišljenju poslušnost osnova dobrog predstavljanja u selekcionoj situaciji. Odmah zatim tu su i značajna sniženja na skalama Odbacivanja (tvrdoglavost, kritičnost) i Agresije (sklonost svađi, nesaradljivost) - sam opis skala dovoljno govori o logičnosti ovih promena. Značajan porast beleže i skale Zaštite (oprez, poslušnost, nesigurnost) i Reprodukcije (društvenost).

Tabela 5. Scheffe test, razlike u skorovima izmedu normativnog i instruisanog merenja

\begin{tabular}{llll}
\hline SKALA & razlika AS & St. greška & $p$ \\
\hline INKORPORACIJA & 20.30 & 8.30 & .00 \\
ZAŠTITA & 12.80 & 8.30 & .00 \\
ORIJENTACIJA & -6.37 & 8.30 & .89 \\
LIŠENOST & -3.20 & 8.30 & .99 \\
ODBACIVANJE & -15.58 & 8.30 & .00 \\
AGRESIJA & -15.07 & 8.30 & .00 \\
ISTRAŽIVANJE & 3.19 & 8.30 & .99 \\
REPRODUKCIJA & 12.07 & 8.30 & .00 \\
\hline
\end{tabular}

Interesantno je ispitati i interakciju merenja sa oblastima obrazovanja, i videti da li se ispitanici humanističke i tehničke struke razlikuju po stepenu lažiranja. Pokazalo se da su ispitanici humanističkih struka spretniji kada je u pitanju samopredstavljanje, s obzirom da su lažirali rezultate na tri skale. U pitanju su skale Inkorporacije, Odbacivanja i Agresije. Kod ispitanika tehničkih struka nisu zabeležene statistički značajne razlike na dva merenja. Objašnjenje za ovu razliku nalazimo u pregledu standardnih devijacija na pomenute tri skale - one su kod humanističke oblasti u proseku duplo manje nego kod tehničara. To navodi na zaključak da humanisti imaju uniformnu sliku idealnog kandidata, za razliku od tehničara čiji su se raznovrsni pokušaji lažiranja vero- 
vatno potirali na grupnom nivou. U Tabeli 6. se nalazi deskriptivna statistika, a u Tabeli 7. su izdvojene skale na kojima su razlike značajne.

Tabela 6. Deskriptivna statistika, razlika izmedu normativnog i instruisanog merenja izmedu dve oblasti obrazovanja

\begin{tabular}{lllll}
\hline & \multicolumn{2}{l}{ humanistička oblast } & \multicolumn{2}{l}{ tehnička oblast } \\
\cline { 2 - 5 } & $\begin{array}{l}\text { normativno } \\
\text { merenje }\end{array}$ & $\begin{array}{l}\text { instruisano } \\
\text { merenje }\end{array}$ & $\begin{array}{l}\text { normativno } \\
\text { merenje }\end{array}$ & $\begin{array}{l}\text { instruisano } \\
\text { merenje }\end{array}$ \\
\hline SKALA & AS (SD) & AS (SD) & AS (SD) & AS (SD) \\
\hline INKORPORACIJA & $76.69(25.63)$ & $88.28(15.84)$ & $68.02(30.15)$ & $71.95(32.45)$ \\
ZAŠTITA & $68.65(25.90)$ & $75.77(22.39)$ & $68.37(25.66)$ & $70.90(22.12)$ \\
ORIJENTACIJA & $41.66(26.29)$ & $37.44(24.40)$ & $40.33(25.54)$ & $39.16(22.80)$ \\
LIŠENOST & $47.25(27.66)$ & $46.34(26.62)$ & $51.72(29.13)$ & $50.84(30.49)$ \\
ODBACIVANJE & $30.40(24.84)$ & $20.68(18.85)$ & $38.07(27.96)$ & $35.90(28.89)$ \\
AGRESIJA & $27.40(24.42)$ & $18.25(17.28)$ & $36.97(27.60)$ & $34.29(28.83)$ \\
ISTRAŽIVANJE & $61.92(24.60)$ & $63.99(20.54)$ & $60.48(24.75)$ & $60.27(20.74)$ \\
REPRODUKCIJA & $72.63(27.29)$ & $79.96(21.36)$ & $61.89(31.36)$ & $59.92(33.37)$ \\
\hline
\end{tabular}

Tabela 7. Scheffe test, značajne razlike između normativnog i instruisanog merenja za ispitanike iz dve oblasti obrazovanja

\begin{tabular}{lllll}
\hline & & & Standardna \\
& SKALA & razlika AS & greška & $\mathrm{p}$ \\
\hline \multirow{2}{*}{$\begin{array}{l}\text { humanistička } \\
\text { oblast }\end{array}$} & INKORPORACIJA & 24.22 & 14.73 & .00 \\
& ODBACIVANJE & -20.19 & 14.73 & .01 \\
& AGRESIJA & -19.12 & 14.73 & .01 \\
\hline \multirow{2}{*}{ tehnička oblast } & - & & & \\
& & & & \\
\hline
\end{tabular}

S obzirom da žene čine većinu uzorka ispitanika humanističkih nauka, ispitana je i interakcija merenja sa polom. Dobijen je rezultat veoma sličan gornjem. Dok muškarci nisu lažirali rezultate ni na jednoj skali, žene su „prevarile" tri skale. Ponovo su u pitanju iste tri skale: Inkorporacija, Odbacivanje i Agresija. I ovde se objašnjenje krije u poređenju standardnih devijacija - one su mnogo niže kod žena, što ponovo ukazuje na uniformnost njihovog odgovaranja. U Tabeli 9. su izdvojene samo skale na kojima su razlike značajne. 
Tabela 8. Deskriptivna statistika, muškarci $i$ žene, razlika izeđu normativnog i instruisanog merenja

\begin{tabular}{lllll}
\hline & muškarci & \multicolumn{2}{l}{ žene } \\
\cline { 2 - 5 } & $\begin{array}{l}\text { normativno } \\
\text { merenje }\end{array}$ & $\begin{array}{l}\text { instruisano } \\
\text { merenje }\end{array}$ & $\begin{array}{l}\text { normativno } \\
\text { merenje }\end{array}$ & $\begin{array}{l}\text { instruisano } \\
\text { merenje }\end{array}$ \\
\hline SKALA & AS (SD) & AS (SD) & AS (SD) & AS (SD) \\
\hline INKORPORACIJA & $62.20(31.99)$ & $65.55(35.62)$ & $78.88(23.51)$ & $88.58(14.70)$ \\
ZAŠTITA & $66.94(27.23)$ & $68.23(25.88)$ & $69.43(24.90)$ & $76.13(20.72)$ \\
ORIJENTACIJA & $39.15(26.54)$ & $34.71(22.41)$ & $42.16(25.58)$ & $39.17(24.25)$ \\
LIŠENOST & $57.66(27.77)$ & $60.90(27.60)$ & $44.45(27.65)$ & $43.40(26.81)$ \\
ODBACIVANJE & $41.32(30.01)$ & $40.58(33.27)$ & $29.55(23.31)$ & $20.84(17.00)$ \\
AGRESIJA & $41.66(28.84)$ & $42.26(31.21)$ & $25.97(22.89)$ & $17.38(15.21)$ \\
ISTRAŽIVANJE & $61.77(26.38)$ & $61.37(22.84)$ & $61.00(23.66)$ & $63.17(19.87)$ \\
REPRODUKCIJA & $58.19(32.79)$ & $55.90(36.05)$ & $73.34(26.18)$ & $79.01(21.33)$ \\
\hline
\end{tabular}

Tabela 9. Scheffe test, muškarci i žene, značajne razlike između normativnog i instruisanog merenja

\begin{tabular}{lllll}
\hline & & & Standardna & \\
& SKALA & razlika AS & greška & p \\
\hline \multirow{2}{*}{ žene } & INKORPORACIJA & 20.906 & 13.84 & $\mathbf{. 0 0}$ \\
& ODBACIVANJE & -18.072 & 13.84 & $\mathbf{. 0 1}$ \\
& AGRESIJA & -18.133 & 13.84 & $\mathbf{. 0 1}$ \\
\hline \multirow{2}{*}{ muškarci } & - & & & \\
\hline
\end{tabular}

Trostrukom interakcijom (merenje, pol, oblast obrazovanja) samo su potvrđeni gornji nalazi - dok na normativnom merenju nema razlika između muškaraca tehničkih struka i žena humanističkog usmerenja, na instruisanom merenju žene postižu bolje rezultate na tri skale. Značajne razlike nalaze se u Tabeli 10.

Tabela 10. Scheffe test, značajne razlike između muškaraca-tehničkog obrazovanja $i$ ženahumanističkog obrazovanja na normativnom $i$ instruisanom merenju

\begin{tabular}{lllll}
\hline & SKALA & razlika AS & $\begin{array}{l}\text { Standardna } \\
\text { greška }\end{array}$ & $\mathbf{p}$ \\
\hline \multirow{2}{*}{ instruisano } & INKORPORACIJA & -31.897 & 26.642 & $\mathbf{. 0 2 4}$ \\
merenje & AGRESIJA & 32.447 & 26.642 & $\mathbf{. 0 1 5}$ \\
& REPRODUKCIJA & -35.295 & 26.642 & $\mathbf{. 0 0 0}$ \\
\hline normativno & & & & \\
merenje & & & & \\
\hline
\end{tabular}


$\mathrm{Na}$ osnovu prve sprovedene analize, može se izvesti zaključak da je test PIEJRS delimično podložan lažiranju. Dok su tri skale demonstrirale otpornost na lažiranje, za pet skala to ne možemo reći. Prilikom instruisanog lažiranja, ispitanici se najviše trude da se predstave kao poslušni i nekonfliktni kandidati (podizanjem skora na Inkorporaciji i snižavanjem Agresije i Odbacivanja). Ovakav obrazac u odgovaranju je naročito uočljiv kod žena i pripadnika humanističkih struka, dok muškarci i pripadnici tehničkih struka nisu uspeli da lažiraju ni jednu od skala. Pretpostavka je da žene i humanisti imaju jasniju predstavu kada je pozitivno predstavljanje u pitanju, dok kod preostalog dela uzorka direkcija u mišljenju nije bila tako uniformna. To dokazuju i razlike u standardnim devijacijama, koje su kod žena i humanista na pomenute tri skale u proseku duplo manje. Dakle, muškarci i tehničari nemaju standardnu sliku idealnog kandidata, tako da su se njihovi pokušaji lažiranja izgubili na grupnom nivou.

\section{Druga etapa}

Druga etapa istraživanja odgovara na pitanje da li kandidati za posao koriste mogućnost lažiranja u situaciji profesionalne selekcije? Da bi se ispunio ovaj cilj, izvršeno je poređenje rezultata koje su postigli ispitanici instruisani da lažiraju rezultate u fiktivnoj selekcionoj situaciji i kandidati koji su se nalazili u realnoj situaciji profesionalne selekcije. Na osnovu deskriptivne statistike je uočljivo da razlike između fiktivne i realne selekcione situacije nisu velike (Tabela 11).

Tabela 11. Prosečni skorovi na skalama PIE za fiktivnu i realnu selekcionu situaciju

\begin{tabular}{lll}
\hline & fiktivna selekcija & realna selekcija \\
\hline SKALA & AS (SD) & AS (SD) \\
\hline INKORPORACIJA & $81.40(24.70)$ & $77.73(21.81)$ \\
ZAŠTITA & $71.83(24.63)$ & $72.02(23.26)$ \\
ORIJENTACIJA & $40.26(25.03)$ & $42.87(24.73)$ \\
LIŠENOST & $47.81(27.52)$ & $44.91(27.58)$ \\
ODBACIVANJE & $27.08(24.96)$ & $31.35(22.42)$ \\
AGRESIJA & $26.39(25.37)$ & $29.78(23.88)$ \\
ISTRAŽIVANJE & $60.77(22.58)$ & $58.94(25.25)$ \\
REPRODUKCIJA & $73.83(26.94)$ & $73.61(24.70)$ \\
\hline
\end{tabular}


U cilju utvrđivanja razlika između grupa, korišćena je dvosmerna multivarijatna analiza kovarijanse. Kao zavisne varijable su uvršteni skorovi na osam skala PIE-JRS, dok su kao kategorijalni prediktori korišćeni grupa (fiktivna/realna selekcija) i pol. Oblast obrazovanja nije uključena u ovu analizu usled nedovoljnog broja ispitanika u pojedinim kategorijama i velikog broja nedostajućih podataka. Kao kovarijat je korišćena varijabla starost (izražena u godinama), u cilju kontrolisanja efekta starosti, s obzirom da su ispitanici iz grupe realnih kandidata u proseku stariji za tri godine.

Tabela 12. MANCOVA - efekti kategorijalnih prediktora i njihove interakcije

\begin{tabular}{llll}
\hline & Wilks' Lambda & F & p \\
\hline STAROST & 0.94 & 4.04 & $\mathbf{. 0 0}$ \\
GRUPA & 0.94 & 3.98 & $\mathbf{. 0 0}$ \\
POL & 0.63 & 38.36 & $\mathbf{. 0 0}$ \\
GRUPA $\times$ POL & 0.96 & 2.37 & $\mathbf{. 0 2}$ \\
\hline
\end{tabular}

Rezultati MANCOVA-e pokazuju da su značajni svi glavni efekti, kao i interakcija grupe i pola. Kako je na osnovu deskriptivne statistike uočeno da razlike među grupama nisu velike, ovaj nalaz je potrebno detaljnije ispitati. U tu svrhu je sprovedeno osam univarijatnih analiza kovarijanse sa skalama PIE-JRS kao zavisnim varijablama. Rezultati se nalaze u Tabeli 13.

U svakoj od osam univarijatnih analiza od najveće važnosti za naše istraživačko pitanje je efekat Grupe, koji govori o razlici između skorova u fiktivnoj i realnoj selekcionoj situaciji. Taj efekat je zabeležen na tri skale: Zaštita, Lišenost i Agresija. Kandidati iz realne selekcione situacije postižu više skorove na Zaštiti (oprez, poslušnost) nego kandidati iz fiktivne situacije. Na Lišenosti (potištenost, pesimizam) i Agresiji (sklonost svađi, nesaradljivost), realni kandidati beleže niži skor od fiktivnih. Sa stanovišta profesionalne selekcije i odluke o zapošljavanju, sva tri nalaza idu u prilog realnim kandidatima, koji postižu poželjnije rezultate.

Efekti pola, starosti i interakcije pol-grupa dobijeni su na više skala. Kako je ovom prilikom u prvom planu utvrđivanje razlika između grupa a ne polnih i starosnih razlika, ovi efekti neće biti detaljnije razmatrani. 
Tabela 13. Osam dvofaktorskih ANCOVA - efekti kategorijalnih prediktora i njihova interakcija

\begin{tabular}{|c|c|c|c|c|}
\hline ZAVISNAVAR. & EFEKTI & $\mathrm{F}$ & $\mathrm{p}$ & Beta \\
\hline \multirow{4}{*}{$\begin{array}{l}\text { INKORPORACIJA } \\
(\mathrm{R}=.429, \mathrm{p}=.000)\end{array}$} & STAROST & .04 & .83 & .01 \\
\hline & GRUPA (fiktivni spram realnih) & .38 & .54 & -.03 \\
\hline & POL (muški spram ženskog) & 114.49 & .00 & -.43 \\
\hline & GRUPA $\times$ POL & 1.81 & .18 & -.05 \\
\hline \multirow{4}{*}{$\begin{array}{l}\text { ZAŠTITA } \\
(\mathrm{R}=.251, \mathrm{p}=.000)\end{array}$} & STAROST & 1.65 & .20 & -.06 \\
\hline & GRUPA (fiktivni spram realnih) & 4.14 & .04 & -.10 \\
\hline & POL (muški spram ženskog) & 32.20 & .00 & -.24 \\
\hline & GRUPA $\times$ POL & 1.05 & .31 & -.04 \\
\hline \multirow{4}{*}{$\begin{array}{l}\text { ORIJENTACIJA } \\
(\mathrm{R}=.102, \mathrm{p}=.233)\end{array}$} & STAROST & 3.65 & .06 & .10 \\
\hline & GRUPA (fiktivni spram realnih) & .01 & .94 & -.00 \\
\hline & POL (muški spram ženskog) & .00 & .98 & -.00 \\
\hline & GRUPA $\times$ POL & .11 & .75 & .01 \\
\hline \multirow{4}{*}{$\begin{array}{l}\text { LIŠENOST } \\
(\mathrm{R}=.271, \mathrm{p}=.000)\end{array}$} & STAROST & .97 & .33 & -.05 \\
\hline & GRUPA (fiktivni spram realnih) & 3.88 & .05 & .10 \\
\hline & POL (muški spram ženskog) & 40.26 & .00 & .27 \\
\hline & GRUPA $\times$ POL & .06 & .81 & .01 \\
\hline \multirow{4}{*}{$\begin{array}{l}\text { ODBACIVANJE } \\
(\mathrm{R}=.388, \mathrm{p}=.000)\end{array}$} & STAROST & .32 & .57 & .03 \\
\hline & GRUPA (fiktivni spram realnih) & .25 & .62 & .02 \\
\hline & POL (muški spram ženskog) & 86.79 & .00 & .38 \\
\hline & GRUPA $\times$ POL & 1.81 & .18 & .06 \\
\hline \multirow{4}{*}{$\begin{array}{l}\text { AGRESIJA } \\
(\mathrm{R}=.495, \mathrm{p}=.000)\end{array}$} & STAROST & 2.31 & .13 & .07 \\
\hline & GRUPA (fiktivni spram realnih) & 4.32 & .04 & .09 \\
\hline & POL (muški spram ženskog) & 163.08 & .00 & .49 \\
\hline & GRUPA $\times$ POL & 2.53 & .11 & .06 \\
\hline \multirow{4}{*}{$\begin{array}{l}\text { ISTRAŽIVANJE } \\
(\mathrm{R}=.130, \mathrm{p}=.060)\end{array}$} & STAROST & .42 & .52 & -.03 \\
\hline & GRUPA (fiktivni spram realnih) & .02 & .88 & -.01 \\
\hline & POL (muški spram ženskog) & 2.36 & .13 & -.07 \\
\hline & GRUPA $\times$ POL & 4.77 & .03 & -.10 \\
\hline \multirow{4}{*}{$\begin{array}{l}\text { REPRODUKCIJA } \\
(\mathrm{R}=.283, \mathrm{p}=.000)\end{array}$} & STAROST & 10.29 & .00 & .16 \\
\hline & GRUPA (fiktivni spram realnih) & .01 & .91 & .01 \\
\hline & POL (muški spram ženskog) & 33.10 & .00 & -.25 \\
\hline & GRUPA $\times$ POL & 6.85 & .01 & -.11 \\
\hline
\end{tabular}

Dakle, na pet skala testa PIE-JRS nema razlike između ispitanika instruisanih da lažiraju rezultate i realnih kandidata, a na preostalih tri realni kandidati postižu poželjnije rezultate. Na osnovu druge etape možemo zaključiti da kandidati na procesu selekcije zaista koriste mogućnost lažiranja odgovora. 


\section{Diskusija}

Prva etapa istraživanja ponudila je odgovor na pitanje da li je test PIE-JRS otporan na namerno lažiranje skorova u smislu boljeg predstavljanja. Pokazalo se da je njegova otpornost samo delimična - ispitanici su pod instrukcijom da se predstave u što boljem svetlu uspeli da lažiraju pet od osam skala ovog testa. Skorovi na svim skalama su doživeli promene u logičnom pravcu - poželjne dimenzije su povišene, a nepoželjne snižene. Prosečna razlika između skorova na normativnom i instruisanom merenju iznosi trećinu standardne devijacije. To je u saglasnosti sa istraživanjem koje su sproveli Jackson i saradnici (2000), koji su koristili sličan nacrt, takođe sa testom prinudnog izbora. Isti autori su utvrdili da se na testovima Likertovog tipa beleže povećanja od cele standardne devijacije, tako da možemo reći da PIE-JRS poseduje određeni stepen moći da ublaži efekte lažiranja.

Najranjivijom u smislu lažiranja se pokazala skala Inkorporacije, čiji visoki skorovi govore o poslušnosti i prihvatanju drugih ljudi. Visoku podložnost lažiranju su pokazale i dve "negativne“ skale: Odbacivanja i Agresije, čiji su skorovi drastično umanjeni nakon instrukcije, kao i Zaštita i Reprodukcija. Nakon pregleda ovih skala donekle je jasan obrazac razmišljanja kandidata u procesu profesionalne selekcije: predstaviti se kao poslušna, nekonfliktna osoba. Izbor ispitanika-kandidata da prate baš takav obrazac može se objasniti samom prirodom profesionalne selekcije. Kompletan proces (koji uključuje kontakt poslodavca sa kandidatom, testiranje i intervju) stavlja kandidata u podređeni položaj, s obzirom da je on taj koji je procenjivan. Jedan od osnovnih ciljeva tokom tog procesa za većinu kandidata je da ne naprave grešku u smislu agresivnih ispada, otkrivanja slabosti ili "nasedanja na provokaciju“ od strane procenitelja. Konfliktno ponašanje je vrlo nepoželjno u očima poslodavaca i neprihvatljivo u procesu selekcije. Upravo zato se poslušnost čini kao najsigurniji izbor, jer minimizuje rizik pravljenja većih grešaka.

Bilo je za očekivati da će kandidati različitih struka imati različite direkcije u mišljenju kada je pozitivno samopredstavljanje u pitanju. Naše istraživanje je ponudilo određeni uvid u postojanje takvih razlika. Obrazac poslušnosti je karakterističan za žene i pripadnike humanističkih struka. To se može objasniti postojanjem jasne predstave kako izgleda idealan kandidat, odnosno uniformnim stilom odgovaranja kod tih delova uzorka (zapravo, ta dva dela uzorka se u velikoj meri preklapaju, s obzirom da žene čine većinu poduzorka humanističke oblasti obrazovanja). S druge strane, muškarci i pripadnici tehničkih struka nemaju jedinstvenu direkciju u mišljenju kada je u pitanju profil idealnog kandidata. To je dovelo do velike raznovrsnosti u profilima na ins- 
truisanom merenju i odsustva prepoznatljivog obrasca na grupnom nivou. Sasvim je logično da za jedan deo tog poduzorka suština pozitivnog samopredstavljanja nije u poslušnosti, već u agresivnosti i prodornosti, kao poželjnim osobinama u mnogim profesijama. Nažalost, ovo istraživanje usled ograničenja koja je nametnuo prigodan uzorak, ne može da detaljnije objasni ove razlike. Varijabla koja bi mogla da ponudi odgovor na ovo pitanje je vrsta posla koju ispitanici imaju na umu kada lažiraju odgovore na instruisanom merenju.

Tri skale su se pokazale otpornim na lažiranje: Orijentacija, Lišenost i Istraživanje. Za praktičare-korisnike ovog testa je svakako dobra vest da se skala Istraživanja pokazala otpornom, s obzirom da ona govori o organizovanosti, preciznosti i planiranju, osobinama koje su bitne za mnoge radne pozicije (poslovni sekretar, računovođa i slično). Isto važi i za Lišenost, koja obuhvata set nepoželjnih osobina: potištenost, pesimizam i osećaj besmisla. Skala Orijentacije je blago snižena u instruisanoj situaciji (nedovoljno da dostigne statističku značajnost), što se uklapa u sliku poslušnosti kojoj su težili ispitanici.

Spisak lažiranih skala se ne poklapa sa nalazima autora testa, koji je identifikovao Istraživanje i Reprodukciju kao skale podložne lažiranju (Kostić, 2003). Osnovni razlog za ovu nedoslednost nalazimo u različitim uzorcima - u pomenutom istraživanju uzorak su činili isključivo muškarci, kandidati za prijem u vojnu školu. U skladu sa gornjim nalazima, objašnjenje nalazimo u specifičnosti obrasca lažiranja koji poseduju kandidati za vojnu školu, odnosno njihovim pretpostavkama o tome šta znači dobro se predstaviti.

Da li podložnost lažiranju ovog testa automatski znači da kandidati u profesionalnoj selekciji koriste tu mogućnost? Drugi segment našeg istraživanja je ponudio potvrdan odgovor na ovo pitanje. Na većini subskala ovog testa nema razlika između skorova na fiktivnoj i realnoj situaciji profesionalne selekcije, a razlike koje su zabeležene idu u prilog realnim kandidatima, što dodatno potvrđuje da je lažiranje prisutno prilikom praktične primene. Ovaj nalaz svakako ne uliva optimizam brojnim korisnicima ovog testa, kako psiholozima tako i poslodavcima. Ipak, ova studija ne bi trebalo da obeshrabri javnost kada je upotreba testa PIE-JRS u selekciji u pitanju, već da podigne svest o njegovim ograničenjima.

Možda je i najvažniji nalaz ovog istraživanja otkrivanje koje skale su najpodložnije lažiranju, što može predstavljati značajnu pomoć praktičarima prilikom interpretacije profila. Praktičari bi na osnovu ovih uvida mogli preokrenuti situaciju u svoju korist. Naime, ranije je utvrđeno da sposobnost lažiranja zapravo predstavlja meru adaptabilnosti, motivacije i inteligencije kandidata, od- 
nosno njihove sposobnosti da se prilagode zahtevima konkursa (Heggestad et al., 2006; Kostić, 2003). Saznanje o tome može pružiti dodatnu informaciju proceniteljima, naročito u smislu lakše eliminacije kandidata koji postižu niže skorove na „poželjnim“ dimenzijama. Za njih možemo zaključiti da ne poseduju tražene osobine i da istovremeno nemaju sposobnost da se predstave $u$ boljem svetlu (ili nisu dovoljno motivisani za to). S obzirom da visoki skorovi mogu imati osnovu i u realnosti i u sposobnosti lažiranja, tu je situacija manje jasna. Ne treba zanemariti i da se testovi ličnosti u profesionalnoj selekciji koriste uglavnom kao pomoćno sredstvo - dopuna intervjuu i testovima sposobnosti, a ne kao jedini sudija o tome ko dobija posao, a ko ne. Upravo zato nalaz o delimičnoj podložnosti lažiranju testova prinudnog izbora ne treba da odvrati praktičare od njihove upotrebe, već da potvrdi njihovu pomagačku ulogu u profesionalnoj selekciji. Sposobnost donošenja validne odluke u profesionalnoj selekciji mora se i dalje oslanjati na veštinu procenjivača da na pravi način objedini opservacije sa testovnim rezultatima. S druge strane, osnovni zadatak za dalja istraživanja predstavlja pronalaženje preciznijih mera za uočene nedostatke.

Najveću slabu tačku ovog istraživanja čini uzorak. Prigodan po svom karakte$\mathrm{ru}$, uzrokovao je par nedostataka u istražavanju. Pre svega, uzorci realnih i fiktivnih kandidata se razlikuju po strukturi - fiktivni kandidati su mahom bili studenti (i to pretežno psihologije i građevine), dok je procenat studenata među realnim kandidatima nizak. Realni kandidati su u proseku i stariji za tri godine (što je ipak kontrolisano uključivanjem $u$ analizu varijable starosti kao kovarijata). Takođe, uzorak ne nudi raznovrsnost po pitanju oblasti obrazovanja, tako da je prva analiza obuhvatala samo dve kategorije, a u drugoj je ova varijabla morala da bude eliminisana usled malog broja ispitanika u pojedinim kategorijama. U narednim istraživanjima dobru alternativu oblastima obrazovanja može da predstavlja varijabla „posao za koji se (fiktivno) konkuriše“, s obzirom da bi takav podatak možda pružio jasniji uvid u obrasce lažiranja.

\section{Zaključak}

U okviru istraživanja su sprovedene dve odvojene analize kako bi se dao odgovor na dva istraživačka pitanja. Prvo se odnosilo na mogućnost namernog lažiranja testa PIE-JRS. Na osnovu prve sprovedene analize, zabeležena je delimična podložnost lažiranju ovog testa - tri skale su demonstrirale otpornost na lažiranje, dok pet skala nije. Prosečna razlika između skorova na normativnom i instruisanom merenju iznosi trećinu standardne devijacije, tako da možemo reći da PIE-JRS poseduje određeni stepen moći da ublaži efekte lažiranja. 
Prilikom instruisanog lažiranja, ispitanici su se najviše trudili da se predstave kao poslušni i nekonfliktni kandidati (podizanjem skora na skali Inkorporacije i snižavanjem Agresije i Odbacivanja). Ovakav obrazac u odgovaranju je naročito uočljiv kod žena i pripadnika humanističkih struka.

$\mathrm{Na}$ osnovu druge etape istraživanja možemo zaključiti da kandidati na procesu selekcije zaista koriste mogućnost lažiranja odgovora - kada se porede ispitanici iz fiktivne i realne profesionalne selekcije, na pet skala testa PIE-JRS nema razlika, a na preostale tri (Zaštita, Lišenost i Agresija) realni kandidati postižu poželjnije rezultate.

\section{Reference}

Christiansen, N.D., Burns, G.N., \& Montgomery, G.E. (2005). Reconsidering forced-choice item formats for applicant personality assessment. Human Performance, 18, 267-307.

Ellingson, J.E., Sackett, P.R., \& Connelly, B.S. (2007). Personality assessment across selection and development contexts: Insights into response distortion. Journal of Applied Psychology, 92, 386-395.

Goffin, R.D., \& Christiansen, N.D. (2003). Correcting personality tests for faking: A review of popular personality tests and an initial survey of researchers. International Journal of Selection and Assessment, 11, 340344.

Heggestad, E.D., Morrison, M., Reeve, C.L. \& McCloy, R.A. (2006). Forced-choice assessments of personality for selection: Evaluating issues of normative assessment and faking resistance. Journal of Applied Psychology, 91, 9-24.

Jackson, D.N., Wroblewski, V.R. \& Ashton, M.C. (2000). The impact of faking on employment tests: Does forced choice offer a solution? Human Performance, 13, 371-388.

Judge, T.A., Klinger, R., Simon, L.S., \& Yang, I.W.F. (2008). The contributions of personality to organizational behavior and psychology: Findings, criticisms, and future research directions. Social and Personality Psychology Compass 2, 1982-2000. Retrieved Jan 05, 2009 from: http://www.ufstudies.net/tim/VITA

Kostić, P. (2003). Priručnik PIE-JRS. Profil indeks emocija, Jugoslovenska revizija i standardizacija, treće izdanje. Beograd: Centar za primenjenu psihologiju. 
Kurbalija, D. (2006). Struktura testa Profil indeks emocija. Psihologija, 39,343359.

Ones, D.S., Viswesvaran, C., \& Reiss, A.D. (1996). Role of social desirability in personality testing for personnel selection: The red herring. Journal of Applied Psychology, 81, 660-679.

Ones, D.S., Viswesvaran, C. \& Schmidt, F.L. (1993). Comprehensive metaanalysis of integrity test validities: Findings and implications for personnel selection and theories of job performance. Journal of Applied Psychology, 78, 679-703.

Rosse, J.G., Stecher, M.D., Miller, J.L., \& Levin, R.A. (1998). The impact of response distortion on preemployment personality testing and hiring decisions. Journal of Applied Psychology, 83, 634-644.

Sackett, P.R. (1994). Integrity testing for personnel selection. Current Directions In Psychological Science, 3, 73-76.

Schmit, M.J., \& Ryan, A.M. (1993). The Big Five in personnel selection: Factor structure in applicant and nonapplicant populations. Journal of Applied Psychology, 78, 966-974. 


\title{
Abstract \\ POSSIBILITY OF FAKING EMOTIONS PROFILE INDEX TEST IN PERSONNEL SELECTION
}

\author{
Predrag Okanović, Dragana Okanović
}

This Research is conducted in order to address two questions: is it possible to intentionally fake scores on Emotions Profile Index in purpose of positive selfpresentation, and do the job candidates utilize this possibility during personnel selection process? Overall sample $(\mathrm{N}=539)$ consisted of two groups: (1) the first group filled this test in two ways (the first time honestly, and the second time with the instruction to present themselves in the best possible way); (2) the second group consisted of job candidates in real personnel selection process. Two separate analyses were conducted in order to provide answers to research questions. According to the first analysis, test partly showed resistance to faking - three subscales proved to be resistant, while the other five didn't. When being instructed to intentionally fake, subjects mostly tended to present themselves as persons who avoid conflict. This pattern is mostly characteristic for women, and social science students. The second analysis showed that job candidates do utilize possibility to fake this test during personnel selection testing - when comparing real and fictive job candidates, real candidates have better results on three scales, and five sub-scales showed no differences.

Key words: faking, Emotions Profile Index, forced-choice test, personnel selection

Primljeno: 2. 3. 2009; prihvaćeno za štampu: 28.10. 2009. 